\title{
The combination of murashige and skoog (MS) media and activated charcoal on the growth of the Vanda helvola orchid plant in vitro
}

\author{
Ata Rofita Wasiati ${ }^{1}$, Ika Afifah Nugraheni*2 ${ }^{2}$, Yuli Setiawati ${ }^{3}$ \\ ${ }^{1}$ Biotechnology Study Program, Faculty of Sains and Technology, 'Aisyiyah Yogyakarta University, Yogyakarta \\ ${ }^{2}$ Head of the plant tissue culture, PT. Biotek Cipta Kreasi, Yogyakarta, Indonesia \\ Yuli Setiawati, PT. Biotek Cipta Kreasi, Yogyakarta, Indonesia \\ ${ }^{1}$ atta.rofita@gmail.com, ${ }^{2}$ ikaafifah @ unisayogya.ac.id*, ${ }^{3}$ yulisetia2011@gmail.com \\ *corresponding author \\ Submission date: 6 April 2021, Receipt date: 5 Mei 2021 ,Publication date: 1 Juli 2021
}

\begin{abstract}
Orchids of the Vanda helvola genus are extensively grown as ornamental plants. The method of propagation of plant seeds in tissue culture is an alternative that may be employed in the provision of a short period. Murashige and Skoog (MS) media and activated charcoal can optimize orchid cultivation utilizing tissue culture techniques. One of the keys to success in tissue culture is the application of natural types of growing regulatory substances (ZPT) at the proper concentration, which can lower the cost of orchid tissue culture. The objective of this study was to see how a combination of Murashige and Skoog (MS) media and activated charcoal influenced the Vanda helvola orchid subculture in vitro. The researchers employed a Complete Randomized Design (RAL) with four treatments and three repeats: negative control (K), $1 / 4 M S(K 1), 1 / 2 M S$ (K2), and 100\% MS (K3) (K3). The observed parameters include the percentage of live explant, number of roots, and height of orchid plants. The results showed that the explant had a 100\% life percentage of over 21 HST and had no noticeable influence on the number of roots and the plant's height.
\end{abstract}

Keywords: MS modifications; vanda helvolaorchid; in vitro; activated charcoal

\section{INTRODUCTION}

Orchid plants, which belong to the Orchidaceae family, are ornamental plants with a high aesthetic value. Orchids feature lovely blooms that come in a variety of sizes, shapes, and colors. Orchid species and varieties are very diverse, including tropical and subtropical areas. Orchid plants are known as the "Queen of Flowers" since their estimated 25,000-30,000 species, and 800 genera have been discovered globally. In Indonesia, there are around 986 species in Java and 971 species in Sumatra forests. 113 species of orchids grow in Maluku, and the rest can be found in Sulawesi, lrian Jaya, Kalimantan, and Nusa Tenggara (Kasutjianingati \& Irawan, 2013). 
Vanda Genus is a widely cultivated orchid species. The entire Orchidaceae family belongs to CITES (Convention on International Trade in Endangered Species of Wild Fauna and Flora) in appendix II. It means that, while its existence is not currently threatened, it will become extinct if a trade is not regulated. The genetics of rare orchid plants can be maintained by embryo or seed culture in vitro. According to Detty et al. (2012), the amount of research on vanda embryo germination is still rather limited. The method of propagation of plant seeds in tissue culture is an alternative that may be employed in the provision of a short period ( $\mathrm{CH} \&$ Gunawan, 2020).

Plant tissue culture isolates cells, tissues, and organs and then grows those parts in artificial media containing rich nutrients and regulatory substances grown under aseptic conditions. These parts can multiply and regenerate into perfect plants again (Aisyah, 2020). The advantages of tissue culture seeds are that the resulting plants are the same parentage, get a lot of plant material, and have a shorter time than waiting for the growth process purely or vegetatively. The plant that can be used as a source of explant is derived from the leaves, roots, bud eyes, pollen, stem ends, and bulbs maintained sterile. Factors that influence success in tissue culture are genotypes, culture media, growing environments, and explants (Nofiyanto et al., 2019).

In increasing the quality and quantity of orchid plants, cultivation techniques must be enhanced. Tissue culture techniques can be used to help produce orchids. Embryo culture/orchid seeds are the most common method for increasing the percentage of growth. Seed culture is the aseptic growth of seeds on an artificial medium under pest conditions. Tissue culture technique through seeds/embryos is done because the size of the seeds is very small or orchid seeds have no endosperm (food reserves), so it is necessary for human help so that the embryo can grow properly. In addition, tissue culture techniques aim to improve seedlings' uniformity in large quantities and relatively short (Widiastoeti et al., 2012)

The success of tissue culture is determined mainly by the media used. The growing media commonly used for orchid germination are Vaccin and Went (VW) media, Knudson C (KC) media, and Murashinge and Skoog (MS) media. The addition of organic materials to the media is now used to help cultivated plants grow faster. Some factors are required for growth, such as the provision of nutrients in the planting media and the addition of organic matter throughout the growth period of orchid embryos (Setiani et al., 2018). The presence of regulatory substances growing in the growth medium determines the growth of the explant. The growing regulatory substances added also vary, both in type and number. Research on the addition of organic matter or growing regulatory substances in planting media has also been widely done, such as coconut water, banana extract, and tomato extract. Based on research (Heriansyah \& Indrawanis, 2020). It is explained that compounds produced by the oxidation of phenols are very toxic for plants and can inhibit growth and differentiation processes. In suppressing the release of the phenol compound, the culture media is given activated charcoal compounds.

Activated charcoal is a porous solid made from carbon-containing materials and heated at high temperatures. It contains $85-95 \%$ carbon. When heating, try not to let air into the room so that carbon-containing materials are just carbonated and not oxidized. Activated charcoal, not only used as fuel but can also be used as an absorbent. Therefore, this study aims to determine the influence of a combination of MS media and activated 
charcoal on the Vanda helvola orchid subculture in vitro.

\section{RESEARCH METHODS}

\section{A. Time and Place of Implementation}

This research activity was conducted at the Plant Tissue Culture Laboratory of PT. Biotek Cipta Kreasi from January 18 to February 22, 2021.

\section{B. Tools and Materials}

The tools used were culture bottles, tweezers, $\mathrm{PH}$ meters, autoclaves, magnetic stirrers, knives, LAF (Laminar Air Flow), Bunsen fire. The materials used were orchid subcultures, Murashige and Skoog (MS - Caisson) media, detergents, sugars, Aquadest, NAOH $1 \mathrm{~N}$ solution, HCL $1 \mathrm{~N}$ solution, gelatin powder, aluminum foil, black plastic, $70 \%$ alcohol, and Benzilaminopurine.

\section{Work Activities}

Here are how fieldwork activities work:

\section{Sterilization of the Room}

Sterilization is carried out every day in the Laboratory of Plant Tissue Culture. Sterilization starts with sterilizing the room by sweeping the room at 08.00 WIB and continuing by turning on the UV light in the room for 15 minutes.

\section{Sterilization of Tools}

All tools such as culture bottles, Petri dishes, tweezers, and measuring cups were washed with liquid soap and rinsed until clean then dried. After drying, the items were wrapped in plastic and sterilized in autoclaves for 30 minutes at 121 ${ }^{\circ} \mathrm{C}$ and 2 atm pressure.

\section{Media Creation}

The components used to make the media made the stock solution first. The growth medium consisted of Murashige and Skoog (MS - Caisson) media with benzilaminopurine growing regulatory substances (BAP - BBI Life Sciences). $4.43 \mathrm{~g}$ of MS was added to $30 \mathrm{~g}$ of sugar and dissolved with an aquades of 1000 $\mathrm{mL}$. The solution was conditioned at a $\mathrm{pH}$ of 5.6-5.8 by adding $\mathrm{NaOH} 1 \mathrm{~N}$ to raise $\mathrm{pH}$ and HCL $1 \mathrm{~N}$ to lower $\mathrm{pH}$. The solution was added to $7 \mathrm{~g}$ gelatin, then stirred with a magnetic stirrer, and heated to a boil. Benzilaminopurine with a final concentration of $1 \mathrm{ppm}$ was added to the medium. The solution was poured into a $25 \mathrm{~mL} /$ bottle \pm culture bottle and covered with aluminum foil. The study used a Complete Randomized Design with four treatments and three repeats. Then the data were analyzed with ANOVA analysis. The following details of the study treatment are:

$\mathrm{K}:$ Added sugar + gelatin + activated charcoal

$\mathrm{K} 1$ : Addition of $1 / 4 \mathrm{MS}+$ sugar + gelatin + activated charcoal

$\mathrm{K} 2$ : Addition of $1 / 2 \mathrm{MS}+$ sugar + gelatin + activated charcoal

$\mathrm{K} 3: 100 \%$ addition of MS +sugar+agar+activated charcoal 


\section{Orchid Subculture}

The explant used in the subculture was a 5-month-old orchid explant with the condition of not growing roots. The planting of the explant was carried out in the LAF (Laminar Air Flow). The LAF was cleaned with 70\% alcohol, irradiated with UV lights for 30 minutes, and the air was allowed to flow for 30 minutes. The explant planting stage was carried out aseptically near the Bunsen fire. In each medium bottle were planted four orchid explants.

\section{Observation}

The observed parameters include the percentage of live explant, the number of roots, and the orchid plant's height. Observations were made at 7 HST, 14 HST, and $21 \mathrm{HST}$. The response assessed or measured from each experimental unit consists of the following parameters:

a. Percentage of explant life (\%)

Observations were made by observing and calculating the number of surviving explants characterized by the continued growth of explant, were not contaminated, and did not die physiologically at the interval of observation once a week. The percentage of life expectancy was calculated using the following formula (Orphan, 2016) :

$$
\text { Percentage of explant life }=\frac{\text { Explant life }}{\text { Total explant }} 100 \%
$$

b. Number of roots (quantity)

The number of roots was observed by counting the roots in a culture bottle on each living plant. Observations were made every two weeks at 7 HST, 14 HST, and $21 \mathrm{HST}$.

c. Plant height $(\mathrm{cm})$

Plant height was observed by measuring the height of the explant in a culture bottle in each living plant. It used a ruler to observe plant heightevery two weeks at the age of 7 HST, 14 HST, and 21 HST.

\section{Data Analysis}

Data from observation of the number of roots and height of orchid plants on the 21st day, then analyzed using the $\mathrm{R}$ data processing application in the form of a one-way ANOVA test at the level of significance of 5\% to prove the hypothesis. If $\mathrm{HO}$ is rejected, the Smallest Real Difference (BNT) test is conducted to determine whether there is a real difference between treatments.

\section{RESULTS AND DISCUSSION}

Subculture or overplanting is the process of transplanting an explant from an old medium to a new medium. The explant is removed under sterile circumstances within the LAF, similar to the treatment of tissue culture planting. Separating, cutting, splitting, and replanting explants that have been developed to increase the number of plants can be done as part of the subculture process (Triharyanto et al., 2018). The explant is transferred from the old media to the new medium to keep the tissue culture 
plant from lacking nutrients and maintaining excellent development. The correct use of ZPT (growing regulatory substances) is a critical factor in tissue culture effectiveness. Based on research that has been done on the influences of the addition of activated charcoal on the growth of the Vanda helvola orchid plant in vitro obtained the following results:

\section{A. Percentage of Explant Life}

The addition of activated charcoal to the growth of the Vanda helvola orchid plant was observed for 21 days. The following observations are presented in Table 1.

Table 1. Percentage of living explant of Vanda helvola orchid plant

\begin{tabular}{cccc}
\hline \multirow{2}{*}{ Treatmenth } & \multicolumn{3}{c}{ Precentage of exsplant life (\%) } \\
\cline { 2 - 4 } & 7 HST & 14 HST & 21 HST \\
\hline K & $100 \%$ & $100 \%$ & $100 \%$ \\
\hline K1 & $100 \%$ & $100 \%$ & $100 \%$ \\
\hline K2 & $100 \%$ & $100 \%$ & $100 \%$ \\
\hline K3 & $100 \%$ & $100 \%$ & $100 \%$ \\
\hline
\end{tabular}

Description:

$\mathrm{K}:$ Added sugar + gelatin + activated charcoal

$\mathrm{K} 1$ : Addition of $1 / 4 \mathrm{MS}+$ sugar + gelatin + activated charcoal

$\mathrm{K} 2$ : Addition of $1 / 2 \mathrm{MS}+$ sugar + gelatin + activated charcoal

$\mathrm{K} 3: 100 \%$ addition of MS +sugar+agar+activated charcoal

Based on the table above, it can be seen that the percentage of explant life in all treatments is $100 \%$. This good explant growth is due to the medium used to meet the initial nutritional needs needed by plants to stay alive. This good explant life ability is due to the explant used in a fresh state. In addition, it is suspected that this also happens because the explant used was able to adapt to the treatment media. Room maintenance also influences the growth of explant. During activities, researchers always did sterilization of the room before and after the activity. Sterilization of the room was done by sweeping the room, turning on UV rays for 15 minutes, and checking contaminated bottles. It aims to reduce the level of contamination in tissue cultures. 


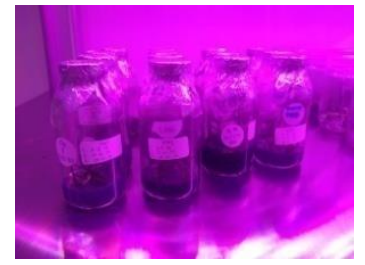

A

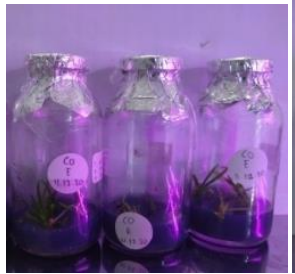

$(\mathrm{K})$

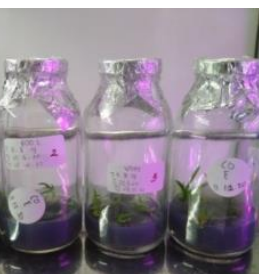

$(\mathrm{K})$

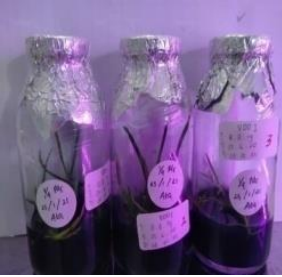

(K1)

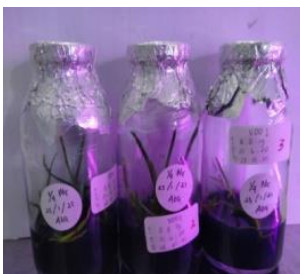

(K2)

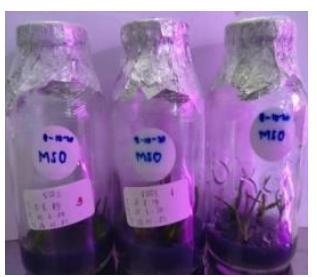

(K3)

B

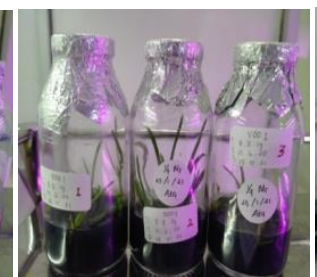

(K1)

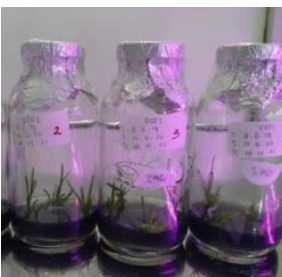

(K2)

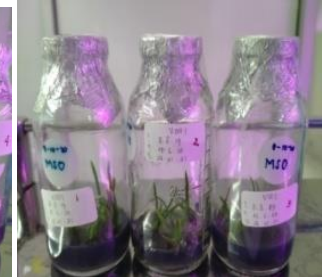

(K3)

C

Figure 3. Orchid subculture result. A) Growth 7 HST, B) Growth 14 HST, C) Growth 21 HST

The Vanda helvola orchid subculture was performed during 21 HST. From subculture $7 \mathrm{HST}$ to $21 \mathrm{HST}$, explant states such as leaf color and stem strength were visually observed. Overall, the explant of the Vanda helvola orchid was fresh green, and the plant's stems did not wither. Detty's research (2015) states that several factors influence the success of subcultures, including the freshness of explants, culture media, environmental conditions, and percentage of explant's life. This statement is further reinforced by Siregar's (2013) opinion that explant selection is a significant element in influencing the effectiveness of plant tissue culture backs up this assertion. According to Triharyanto et al. (2018), with or without the addition of hormones, explants in good physical condition will survive in the culture medium.

\section{B. Number of roots}

The observation results of the explant roots number of orchid plants with MS modification treatment and activated charcoal can be seen in table 2 . 
Table 2. The average number of roots of the Vanda helvola orchid plant

\begin{tabular}{cccc}
\hline \multirow{2}{*}{ Treatment } & \multicolumn{3}{c}{ Observation time } \\
\cline { 2 - 4 } & 7 HST & 14 HST & 21 HST \\
\hline K & 0 & 0 & 1 \\
\hline K1 & 0 & 0 & 1 \\
\hline K2 & 0 & 0 & 1.5 \\
\hline K3 & 0 & 0 & 0 \\
\hline
\end{tabular}

Description:

$\mathrm{K}:$ Added sugar + gelatin + activated charcoal

$\mathrm{K} 1:$ Addition of $1 / 4 \mathrm{MS}+$ sugar + gelatin + activated charcoal

$\mathrm{K} 2$ : Addition of $1 / 2 \mathrm{MS}+$ sugar + gelatin + activated charcoal

$\mathrm{K} 3: 100 \%$ addition of MS +sugar+agar+activated charcoal

Based on table 2, the average number of roots produced ranges from 0-1.5. The average number of roots in $\mathrm{K} 3$ did not increase. While the average number of roots in $\mathrm{K}, \mathrm{K} 1, \mathrm{~K} 2$ increased from the beginning of observation at $7 \mathrm{HST}$ to $21 \mathrm{HST}$. The average number of roots on $\mathrm{K}, \mathrm{K} 1$, and $\mathrm{K} 2$ on the 21 st observation of HST is 1 , 1, and 1.5 , respectively. The highest average root number result is obtained in the K2 treatment of 1.5. The increase in root length in $\mathrm{K} 2$ is due to cell division at the end of the root meristem, followed by the process of lengthening and enlarging the cell.

All treatments have influenced the percentage of growing buds in the explant subculture of the Vanda helvola orchid, although it has a varying percentage of growing buds. The $\mathrm{K} 2$ treatment showed the highest percentage of buds growing. This treatment proves that in growing buds, it did not require a full concentration of MS media and high concentrations of activated charcoal in the explant subculture of the orchid Vanda helvola. The medium of $1 / 2 \mathrm{MS}$ was still very good in growing the subspecialty buds of the Vanda helvola orchid plant, although in a reduced composition. The following research by Purwanto et al. (2008) shows that the media treatment of $1 / 2$ MS causes the highest average percentage of sprouted explants and is different from other treatments.

Widiastoeti et al. (2012) stated that activating charcoal in growing media can indicate the best root length growth. It is because activated charcoal in growing media can reduce the light that enters the media. The low light intensity can stimulate endogenous growing substances to work more actively in carrying out the process of root growth and development. Bright conditions have a real influence on the improvement of explant regeneration capabilities. The auxins in plant tissues can work actively even in the dark, but the synthesis of auxins takes place in a light state. Auxins play a role in the formation and growth of roots. Activated charcoal in the medium will be absorbed by explant roots more optimally than through leaves, especially in plants grown in-vitro to absorb more nutrients through the roots. Activated charcoal gets into the explant root through the roots. The number of roots that grow and develop resulted in the absorption of nutrients in the medium of the orchid subculture to be more effective. 


\section{Plant height}

The average results of observations of the height parameters of orchid explant plants with MS modification treatment and the addition of activated charcoal for 21 HST can be seen in table 3 .

Table 3. The average height of Vanda helvola orchid plant

\begin{tabular}{lcccc}
\hline \multirow{2}{*}{ Perlakuan } & \multicolumn{4}{c}{ Waktu Pengamatan } \\
\cline { 2 - 5 } & 7 HST & 14 HST & 21 HST & akhir-awal \\
\hline K & 1.6 & 1.9 & 2 & 0.4 \\
\hline K1 & 2.3 & 2.9 & 3.2 & 0.9 \\
\hline K2 & 2 & 2.4 & 2.4 & 0.4 \\
\hline K3 & 2.2 & 2.6 & 2.9 & 0.7 \\
\hline
\end{tabular}

Description:

$\mathrm{K}:$ Added sugar + gelatin + activated charcoal

K1 : Addition of $1 / 4 \mathrm{MS}+$ sugar + gelatin + activated charcoal

$\mathrm{K} 2$ : Addition of $1 / 2 \mathrm{MS}+$ sugar + gelatin + activated charcoal

$\mathrm{K} 3: 100 \%$ addition of MS +sugar+agar+activated charcoal

Based on table 3. The average height of the plant obtained after all treatments increased from 7 HST to 21 HST. All treatments influence the height of the vanda helvola orchid subculture explant plant, although it has varying numbers of buds. The K1 treatment of 0.9 indicates the highest number of plants. This treatment proves that the medium of $1 / 4 \mathrm{MS}$ and the addition of activated charcoal is still very good in growing the buds of the vanda helvola orchid subculture plant even in reduced composition and without the addition of exogenous hormones. It is thought to be because MS media contains nutrient elements, both macro, and micro, essential elements in plant growth in vitro. However, the reduced content still affects the high number of plant subcultures of Vanda helvola.

\section{Statistical Analysis}

The ANOVA hypothesis is one-way towards the number of roots as follows:

1. Hypothesis $0(\mathrm{H} 0): \mu_{1}=\mu_{2}=\mu_{3}=\mu_{4}=0$ (The addition of activated charcoal is no different from the number of roots of the Vanda helvola orchid plant)

2. Alternative hypothesis (H1): $\mu_{1}=\mu_{2}=\mu_{3}=\mu_{4}=0$ (The addition of activated charcoal is different from the number of roots of the Vanda helvola orchid plant)

The one-way ANOVA hypothesis on plant height is as follows:

1. Hypothesis $0(\mathrm{H} 0): \mu_{1}=\mu_{2}=\mu_{3}=\mu_{4}=0$ (MS modification and the addition of activated charcoal are no different from the height of the Vanda helvola orchid).

2. Alternative hypothesis (H1): $\mu_{1}=\mu_{2}=\mu_{3}=\mu_{4}=0$ (MS modification and addition of activated charcoal have a real difference to the height of the Vanda helvola orchid plant). 
Table 4. One-way ANOVA statistical analysis results against the number of roots and plant height as follows:

\begin{tabular}{cccccc}
\hline \multirow{2}{*}{ Source of diversity } & \multicolumn{5}{c}{ Number of roots } \\
\cline { 2 - 6 } & DB & JK & KT & F Count & F table \\
\hline Treatment & 3 & 3.9 & 1.3 & 3.4 & 7.58 \\
\hline Galat & 8 & 3.0 & 0.4 & & \\
\hline Total & 11 & 6.9 & \multicolumn{4}{c}{} \\
\hline \multirow{2}{*}{ Source of diversity } & \multicolumn{5}{c}{ Plant height } \\
\cline { 2 - 6 } & DB & JK & KT & F Count & F table \\
\hline Treatment & 3 & 2.4 & 0.8 & 3.4 & 7.58 \\
\hline Galat & 8 & 1.9 & 0.2 & & \\
\hline Total & 11 & 4.3 & & & \\
\hline
\end{tabular}

Based on the fingerprint table, the variety of root numbers can be known. A oneway ANOVA statistical analysis of the number of roots generated F-Count 3,411 and Ftable for a probability of $5 \%$ of 7.58 , so the decision is to accept Ho because $F$-count $<F$ table. It can be interpreted that MS modification and the addition of activated charcoal have noreal difference from the number of roots of the Vanda helvola orchid plant.

According to Detty (2015), in tissue culture research, auxins produce more cytokinin, which stimulates the development of buds and leaves. It will stimulate root development if the concentration of cytokinin is lower than the number of auxins. This investigation also discovered that there is no interaction between MS modification and active charcoal treatment. It is thought to be because the concentration of MS media and activated charcoal added was not optimum and hence had no influence on the number of roots.

The average addition of the height of the Vanda helvola orchid plant with active charcoal treatment ranges from 0.4-0.9 cm (Table 4). After the one-way ANOVA test obtained F-Count $(3,357)$ and F-table $(7.58)$ for a probability of $5 \%$, so the decision is to accept Ho because of F-count $<$ F-table, it can be interpreted to mean that the concentration of MS media. The addition of activated charcoal has noreal difference from the height of the Vanda helvola orchid plant.

The modified treatment of MS media with activated charcoal had no real influence on the number of roots and the height of the Vanda helvola orchid subculture plant. It is thought to be because, in the orchid subculture, plants are slow in absorbing elements contained in media such as cytokinin that serve for cell division in growing buds. The growth of buds depends on specific combinations of factors.According to Hindersah \& Suminar (2020), the combination of active cytokinin plays a role in the doubling of buds and the height of buds until the end of the observation period. However, the number and height of buds formed at the beginning of observation are still low. Sulistiyo et al. (2018) stated that giving cytokinin to culture media causes cell division at the beginning of the culture to be slow, but the cell population is maintained, and then the number is increased. The difference in the number of buds formed in each treatment is influenced by cytokinin at different concentrations. It is following the opinion of Majid et al., (2014) that the 
speed at which a cell divides can be affected by the presence of a particular ZPT combination in a given concentration. According to Shofiyani \& Damajanti (2015), variations in data can occur because each explant has a different cell sensitivity to the stimulation given, such as exogenous hormone stimulation.

Based on Heriansyah \& Indrawanis (2020) stated the addition of activated charcoal to the orchid subculture Dendrobium sp. In this study, activated charcoal can promote growth but has no real influence on the number of roots and height of the Vanda helvola orchid plant. Therefore, there is no need for further tests using the Low Significance Difference (LSD) test. Some of the factors that cause activated charcoal have no real influences,namely, first, the concentration of activated charcoal added has not been optimal. Detty's research (2015) says that the administration of activated charcoal can stimulate the presence of endogenous auxins by causing a dark atmosphere in the medium and long growth of buds. Endogenous auxins will have the opposite influences on cytokinin. It will drive the growth of upward buds to be hampered.

Second, the added activated charcoal does not absorb optimally. According to Heriansyah \& Indrawanis (2020), activated charcoal or carbon is added to the culture media of orchid plant tissues to absorb toxic compounds in the media or to absorb inhibitor substances produced by plants. These additions can help keep the media's $\mathrm{pH}$ stable, promote root development by lowering the quantity of light that reaches the medium and induce morphogenesis. Activated charcoal is a porous solid that can absorb various harmful and beneficial compounds for plants. According to Supriyati (2011), compounds produced by the oxidation of phenols are very toxic for plants and can inhibit growth and differentiation processes. Insuppressing the release of the phenol compound, the culture media is given activated charcoal compounds. However, activated charcoal absorbs harmful chemicals and substances that are beneficial to plant development. Furthermore, activated charcoal can help prevent media browning caused by high temperatures during the sterilizing procedure (Yuniati et al., 2018).

\section{CONCLUSION}

According to the study's findings, modifying MS medium and adding activated charcoal to the development of Vanda helvola orchids resulted in a 100\% percentage of explant life for $21 \mathrm{HST}$ and had no real influence on the number of roots or plant height.

\section{REFERENCES}

Aisyah, I. (2020). Kultur Jaringan Pisang Kepok Tanjung (Tidak Berjantung) Yang Tahan Terhadap Penyakit Darah (Ralstonia Syzygii Subsp. Celebesensis). Deepublish.

CH, R. M., \& Gunawan, H. (2020). Aklimatisasi Dan Adaptasi Pisang Barangan Merah Hasil Kultur Jaringan Dengan Pemberian Nitrogen Dan Media. Prosiding Seminar Nasional Multidisiplin Ilmu Universitas Asahan Ke-4, 1087-1094.

Detty, I. S. (2015). Pengaruh Konsentrasi Thidiazuron (Tdz) dan Arang Aktif Pada Sub Kultur Tunas Pisang Kepok Hijau (Musa Paradisiaca L.) (Doctoral Dissertation, Upt. Perpustakaan Unand). 
Heriansyah, P., \& Indrawanis, E. (2020). Uji Tingkat Kontaminasi Eksplan Anggrek Bromheadia. Jurnal Agroqua, 18(2), 223-232. https://doi.org/10.32663/ja.v

Hindersah, R., \& Suminar, E. (2020). Kendala dan Metode Budidaya Pisang di Beberapa Kebun Petani Jawa Barat. Agrologia, 8(2). https://doi.org/10.30598/a.v8i2.1010

Kasutjianingati, \& Irawan, R. (2013). Media Alternative Perbanyakan In-Vitro Anggrek Bulan (Phalaenopsis amabilis). 3(3), 184-189.

Majid, B., Roopa, G., Sampath, K., Kini, R., Prakash, H., Abbagani, S., Mehdi, K., \& Geetha, N. (2014). Establishment Of An Efficient Explant Surface Sterilization Protocol For In Vitro Micropropagation Of Salacia Chinensis L., An Endangered Anti-Diabetic Medicinal Plant. World Journal of Pharmacy and Pharmaceutical Sciences, 3(12).

Nofiyanto, R. T., Kusmiyati, F., \& Karno, K. (2019). Peningkatan kualitas planlet tanaman pisang raja bulu (Musa paradisiaca) dengan penambahan bap dan iaa pada media pengakaran kultur in vitro. Journal of Agro Complex, 3(3), 132-141. https://doi.org/10.14710/joac.3.3.132-141

Purwanto,AW. (2008). Sansievera flora cantik penyerap racun. Kanisius. Yogyakarta.

Setiani, N. A., Nurwinda, F., \& Astriany, D. (2018). Pengaruh Desinfektan dan Lama Perendaman pada Sterilisasi Eksplan Daun Sukun (Artocarpus altilis (Parkinson ex. F.A Zorn) Fosberg). Biotropika: Journal of Tropical Biology, 6(3), 78-82. https://doi.org/10.21776/ub.biotropika.2018.006.03.01

Shofiyani, A., \& Damajanti, N. (2015). Pengembangan Metode Sterilisasi Pada Berbagai Eksplan Guna Meningkatkan Keberhasilan Kultur Kalus Kencur (Kaemferia galangal L). Agritech, XVII(1), 55-64.

Siregar,I.Z.,N.Khumaida,D.Noviana,M.H.Wibowo, dan Azizah. (2013). Buku Varietas Tanaman Unggul Institut Pertanian Bogor. Institut Pertanian Bogor, Bogor.

Sulistiyo, R. H., Luthfiyyah, Z., Susilo, B., Dalimartha, L. N., Garam, P. T. G., Direktorat, T., \& Gempol, P. (2018). Pengaruh Teknik Sterilisasi dan Komposisi Medium terhadap Pertumbuhan Tunas Eksplan Sirsak Ratu. BIOEDUKASI: Jurnal Pendidikan Biologi, 11, 1-5.

Triharyanto, E., Arniputri, R. B., Muliawati, E. S., \& Trisnawati, E. (2018). Kajian konsentrasi IAA dan BAP pada multiplikasi pisang raja bulu in Vitro dan Aklimatisasinya. Agrotechnology Research Journal, 2(1), 1-5.

Supriyati, Y. (2011). Prospek Teknik Kultur Jaringan untuk Pengadaan Bibit Pisang. Balai Besar Penelitian dan Pengembangan Bioteknologi dan Sumberdaya Genetik Pertanian, Bogor.

Widiastoeti, D., Santi, A., \& Solvia, N. (2012). Pengaruh Myoinositol dan Arang Aktif terhadap Pertumbuhan Planlet Anggrek Dendrobium dalam Kultur In Vitro. Jurnal 
Hortikultura, 22(3), 205-209. https://doi.org/10.21082/jhort.v22n3.2012.p205-209

Yuniati, F., Haryanti, S., \& Prihastanti, E. (2018). Pengaruh Hormon dan Ukuran Eksplan terhadap Pertumbuhan Mata Tunas Tanaman Pisang (Musa paradisiaca var. Raja Bulu) Secara In Vitro. Buletin Anatomi Dan Fisiologi, 3(1), 20. https://doi.org/10.14710/baf.3.1.2018.20-28 